\title{
HEEDING BLACK VOICES: THE COURT, BROWN, AND CHALLENGES IN BUILDING A MULTIRACIAL DEMOCRACY
}

\author{
Joe R. Feagin*
}

In 1967, thirteen years after the first Brown v. Board of Education decision, Dr. Martin Luther King, Jr. voiced great frustration with the lack of progress in societal desegregation: "[e]very civil rights law is still substantially more dishonored than honored. School desegregation is still 90 percent unimplemented across the land. . . Legislation that is evaded, substantially nullified and unenforced is a mockery of the law." Dr. King articulated the views of most African-Americans, views stemming from centuries of painful experiences with systemic racism in U.S. society. Thus, for more than a decade after Brown, white officials in southern districts defied the mandates and implications of Supreme Court and lower federal court rulings and, therefore, the black perspective on U.S. racism and racial change. Indeed, by 1960-1961 only a miniscule 0.16 percent of black children were in school with white children in the South. ${ }^{2}$

Today, a majority of white Americans still reject most of the black perspective on racial discrimination and desegregation in the United States, thereby openly mocking the Brown decision and the civil rights laws passed since the 1960s. Not even half the country's black children today are in schools that are majority white, and there are increasingly fewer white children in public schools in our large central cities. ${ }^{3}$ Even racially integrated schools are, as a rule, internally divided by ability tracking, a secondgeneration segregation of white and black children. ${ }^{4}$ In spite of white support

* Ella C. McFadden Professor, Texas A \& M University. The author wishes to thank Professor Roy Brooks for helpful comments and Danielle Dirks for research assistance.

1. Martin Luther King, Jr., Where Do We Go from Here: Chaos or Community? 11 (1967).

2. Philip A. Klinkner \& Roger s M. Smith, The Unsteady March: The Rise and Decline of RaCial EQUALITY in AMERICA 245 (1999).

3. See Peter Irons, Jim Crow's Children: The Broken Promise of the Brown Decision 338 (2002).

4. The problem of second-generation segregation was well articulated in the 1970s and 1980s by Jennifer Hochschild. See Jennifer L. Hochschild, The New American Dilemma: Liberal Democracy and School Desegregation 31 (1984); Jennifer L. Hochschild, Thirty Years after BROWN 5 (1985). 
in opinion polls for the ideal of a racially desegregated society, a substantial majority of whites have never supported that ideal in practice. ${ }^{5}$

\section{Building a "House of Racism": Some Constitutional Mechanisms}

A few years before the Civil War, and with direct reference to the brutal enslavement of African-Americans, Abraham Lincoln once reiterated the point that a "house divided against itself cannot stand." At that time, the U.S. "house" was divided over the issue of systemic racism taking the form of the widespread enslavement of African-Americans. We can extend this metaphor today to a country still divided by what former Supreme Court Justice William O. Douglas once called the "slavery unwilling to die," that is, by the continuing reality of oppression targeting African-Americans and other Americans of color. The U.S. remains a house with a political-economic foundation built on racial oppression. The white founders espoused, rhetorically and hypocritically, an "all men are created equal" perspective that excluded black Americans, indigenous peoples, and women. The foundation of the new nation was mainly and explicitly crafted to create wealth and privilege for European Americans who had stolen the lands of indigenous peoples and the labor of African-Americans.

The voices and perspectives involved in the creation of the political and economic foundation of the new nation were all those of white men, and the dominant perspectives shaping the country's political, legal, and economic institutions since then have almost always been those of white men. The fiftyfive men meeting in Philadelphia in 1787 were all of European origin, and at least forty percent had been, or were, slave-owners, with many others operating as merchants, lawyers, or bankers profiting from the extensive commerce centered around the slave trade and plantations. ${ }^{8}$ In their new Constitution these white men placed numerous anti-democratic provisions protecting the highly racialized political-economic system of slavery, including: (1) Article 1, Section 2, counting those enslaved as three fifths of

5. See generally Lawrence Bobo et al., Laissez-Faire Racism: The Crystallization of a Kinder, Gentler, Antiblack Ideology, in Racial Attitudes in the 1990s: Continuity and Change 15-40 (Steven A. Tuch \& Jack K. Martin eds., 1997).

6. Abraham Lincoln, A House Divided: Speech Delivered at Springfield, Illinois, at the Close of the Republican State Convention, in ABRAham Lincoln: His Speeches And Writings 372, 372-381 (Roy P. Basler ed., 1946).

7. Jones v. Alfred H. Mayer Co., 392 U.S. 409, 445 (1968) (Douglas, J., concurring). (1986).

8. National Archives and Records Administration, Framers of the Constitution 119 
a person; (2) Article 1, Section 8, giving Congress authority to suppress slave rebellions; (3) Article 1, Section 9, preventing the international slave trade from being abolished before 1808; and (4) Article 4, Section 2, requiring the return of fugitive slaves. ${ }^{9}$ African-Americans made up a fifth of the population at this time, yet not one "founding father" was drawn from their ranks and not one paid serious attention to their perspectives, experiences, and rights in building this new and ostensibly "democratic" nation.

\section{Creating an Undemocratic Political Assembly: The U.S. Senate}

The Constitution of the United States was created in part to guarantee that racial oppression would be at the center of the new nation, and this oppression has remained central ever since. The founders created in the Constitution certain key institutions that were designed to protect the political-economic interests of elite white men. They did not intend to create a democracy where all the people had the right to participate freely in the new political institutions. Thus, among other anti-democratic institutions, they created a U.S. Senate in order, as James Madison put it, "to protect the people against the transient impressions into which they themselves might be led."10 Senators were elected by state legislators (until 1914), not directly by voters, and served staggered six-year terms so a majority could not be replaced in one election and so they would serve longer than members of the more democratic U.S. House. ${ }^{11}$ The Senate soon became a very powerful political body. From the early years, Senate rules have been very useful for senators seeking to maintain the U.S. system of racism. One is the seniority rule, which by 1845 gave control of Senate committees to the dominant party's most senior members. ${ }^{12}$ Another feature that gave senators great power was the absence of a rule to stop debate, which was replaced in 1917 by a weak rule permitting an end to debate on legislation if a cloture motion was approved by two thirds (later 60 percent) of those present and voting. ${ }^{13}$

This oligarchical institution was critical to the protection of the interests of white segregationists well into the 1970s. Using its rules effectively, a small minority of Southern senators were able to block every significant piece

9. See generally Donald E. Lively, The Constitution and Race 4-5 (1992).

10. Robert Caro, The Years of Lyndon Johnson: Master of the Senate 9 (2002) (quoting James Madison).

11. Id. at 9-10.

12. Id. at 78 .

13. Id. at $92-94$. 
of civil rights legislation between the 1870s and the 1964 Civil Rights Act. ${ }^{14}$ The U.S. Senate, as William White put it, is thus "the only place in the country where the South did not lose the [Civil War]." ${ }^{\prime 5}$ Because of the wellplaced, white supremacist senators, racial segregation persisted in the United States from the 1930s until the 1960s, even in the face of great pressure for change. Thus, in a recent book, How Democratic Is the American Constitution?, the country's leading political scientist, Robert A. Dahl, has noted that after two centuries the "Senate has unquestionably failed to protect the fundamental interests of the least privileged minorities. On the contrary ... [it] has sometimes served to protect the most privileged minorities. An obvious case is the protection of the rights of slaveholders rather than the rights of their slaves."16

To the present day, the U.S. Senate, arguably still the world's most powerful political assembly, remains a heavily white-male club. Although white men make up 38 percent of the U.S. population, they constitute 83 percent of the U.S. Senate. In 2002, there were only 14 women and three men of color among the 100 Senators. ${ }^{17}$ White-male interests are still extraordinarily well-represented in, and by, this powerful political assembly.

\section{The Supreme Court: Another Undemocratic Institution}

The U.S. Supreme Court is another constitutional invention that was intentionally created as an unelected body with little democratic overview. Over time, the Court has come to have great unsupervised power, much of it, in effect, legislative: "[n]o other tribunal on earth rivals it. No other government reserves the last word for the judiciary to pronounce." 18 Perhaps the most undemocratic aspect of the Court is this ability to overturn laws passed by a more democratically constituted Congress - by means of the

\footnotetext{
14. Id. at $90-94$.

15. Id. at 94 (quoting William White).

16. Robert A. Dahl, How Democratic Is the American Constitution? 52-53 (2001).

17. The One Hundred Eighth Congress: Composition of the 107th and 108th Congresses, Infoplease, available at $\mathrm{http}: / /$ www.infoplease.com/ipa/A0108853 html (last visited Apr. 16, 2004); What is the Composition of the Congress in Terms of Race, Sex, and Political Party?, This Nation, available at http://www.thisnation.com/question/015.html (last visited Apr. 16, 2004); Sean Loughlin \& Robert Yoon, Millionaires Populate U.S. Senate: Kerry, Rockefeller, Kohl Among the Wealthiest, CNN, available at http://www.cnn.com/2003/ALLPOLITICS/06/13/Senators.finances/index.html(last visited Apr. 16, 2004).

18. Richard Kluger, Simple Justice: The History of Brown V. BOARD of EDUCATion ANd Black America's Struggle for Equality 65 (1975).
} 
constitutionally prescribed doctrine of judicial review. ${ }^{19}$ Thus, the Supreme Court was intentionally placed by the white male founders in the political system to protect that system from what were seen as the often too-democratic impulses of the "masses." 20

The Supreme Court, like the Senate, has long been central to the racial oppression of African-Americans. Until the 1930s, the Court always rejected the experiences and accounts provided by African-Americans in regard to racial segregation and other forms of racial oppression. The all-white-male Justices periodically made it clear that African-Americans did not have any voice in social and legal affairs. In the 1856 case, Dred Scott v. Sandford, the Court's majority asserted that black Americans were "beings of an inferior order, and altogether unfit to associate with the white race, either in social or political relations; and so far inferior that they had no rights which the white man was bound to respect ...." 11 In effect, these white men were, with no apparent sense of contradiction, painting the dimensions of a totalitarian system (that is, one where the state regulates every aspect of one's life without freedom) in regard to nearly a fifth of the country's residents. Indeed, as we will see below, some version of this perspective on black Americans prevailed among a majority of whites, both the ruling elite and the general public, until the mid-20th century.

The Court has spent most of its history since the Civil War expressing the viewpoints and defending the interests of white Americans. Court opinions in the decades between the Civil War and the 1930s often eroded the rights of African-Americans gained under the Fourteenth and Fifteenth Amendments and Reconstruction civil rights legislation. If one turns to landmark Supreme Court Justices' statements on racial matters around the turn of the 20th century, one again finds that virtually all ignore or dismiss the perspectives of black targets of the country's systemic racism. In the influential 1896 Plessy v. Ferguson case, a nearly unanimous court (with one dissenter, John Marshall Harlan) upheld a Louisiana law requiring segregation in public accommodations. ${ }^{22}$ Interestingly, the opinion cited as precedent previous state court cases upholding segregation in public schools. ${ }^{23}$ Segregation in one area made it legitimate in another. Significantly, in 1896 these arrogant Justices

19. See DAHL, supra note 16 , at 54 .

20. KLUGER, supra note 18, at 66-67.

21. Scott v. Sandford, 60 U.S. 393, 407 (1856).

22. Plessy v. Ferguson, 163 U.S. 537, 551-52 (1896).

23. Id. at 544-45; see also Waldo E. MARtin, JR., Brown V. BoARd of EDUCATION: A Brief History with Documents 79-80 (1998). 
asserted that they as white men knew better than the black plaintiff and other African-Americans what harm segregation inflicted upon them:

We consider the underlying fallacy of the plaintiff's argument to consist in the assumption that the enforced separation of the two races stamps the colored race with a badge of inferiority. If this be so, it is not by reason of anything found in the act, but solely because the colored race chooses to put that construction upon it. . . . Legislation is powerless to eradicate racial instincts or to abolish distinctions based upon physical differences .... ${ }^{24}$

Thus, in their view, the Justices need not pay serious attention to the black perspective and experience. In his dissent, Justice Harlan argued for respecting certain rights of black Americans, for the Thirteenth Amendment made unconstitutional "the imposition of any burdens or disabilities that constitute badges of slavery or servitude." ${ }^{25}$ Yet, even Harlan expressed a white-supremacist view: "[t]he white race deems itself to be the dominant race in this country. And so it is, in prestige, in achievements, in education, in wealth, and in power. So, I doubt not, it will continue to be for all time...."

\section{Black Perspectives and Early Action Against Segregation}

Northern whites in Massachusetts created the first extensive public school system in the first half of the 19th century. Under pressure from ordinary white citizens, officials soon created the first school segregation along racial lines. ${ }^{27}$ An African-American parent, Benjamin Roberts, was the first to undertake a major lawsuit to undo this segregation. In 1849, Roberts filed a lawsuit in Boston on behalf of his daughter, who had been denied access to a nearby school because she was "colored." ${ }^{28}$ In the case, the prominent lawyer and abolitionist Charles Sumner argued before the Supreme Judicial Court of Massachusetts that racial segregation labeled "a whole race with the stigma of inferiority and degradation." 29 A segregated school, "so far from being for the benefit of both races, is an injury to both. It tends to create a feeling of degradation in the blacks, and of prejudice and uncharitableness in the

24. Plessy, 163 U.S. at 551.

25. Id. at 555 (Harlan, J., dissenting).

26. Id. at 559 (Harlan, J., dissenting) (emphasis added).

27. Derrick Bell, Brown and the Interest-Convergence Dilemma, in Shades of Brown: New Perspectives on School Desegregation 97 (Derrick Bell ed., 1980).

28. Roberts v. City of Boston, 59 Mass. 198 (1849).

29. IRONS, supra note 3, at 15. 
whites." 30 The white judge, however, did not agree and accepted the nowhoary argument of Boston officials that separating children was in the alleged "interest" of both races. The judge ruled as follows: "[i]t is urged, that this maintenance of separate schools tends to deepen and perpetuate the odious distinction of caste, founded in a deep-rooted prejudice in public opinion. This prejudice, if it exists, is not created by law, and probably cannot be changed by law." ${ }^{11}$ At this early point in time, the white judge not only ignored the black perspective, but also took it upon himself to determine what was in the interest of black parents and children. In subsequent decades, various judges would cite this Roberts decision as a precedent allowing segregation of children by school officials, as well as other forms of racial segregation. ${ }^{32}$

White judges were forced to make rulings on segregation because African-Americans early on were pressing hard for change. Such change has rarely come out of the "goodness of white hearts," but rather has usually, where it occurs, been forced by pressures from black communities. Black parents have struggled for adequate and desegregated schooling since at least the mid-19th century. Indeed, one major irony of recent struggles to desegregate schools in the South is that it was black southerners who had pushed the hardest for public education for the then-backward South after the Civil War. The first major efforts to bring publicly funded education on a large scale to the South were made by black leaders, who took earlier ideas articulated by a few whites and crafted them into a conception of education for all. ${ }^{33}$ For a time during Reconstruction, black southerners participated very actively in many southern legislatures and other local political bodies, and their voices were significant in bringing changes to a South newly liberated not only from slavery, but also from a political autocracy that significantly reduced the liberties of ordinary whites and blacks. As a result, during Reconstruction there was significant racial desegregation of some public accommodations, some schools and colleges, and other institutions. ${ }^{34} \mathrm{~A}$ system of extreme apartheid was not put into place by southern whites (led by elites) until the 1890s and early 1900s, and black Americans fought

30. Id.

31. Roberts, 59 Mass. at 209.

32. IRONS, supra note 3, at 16-18.

33. W.E.B. Du Bois, 200 Years of Segregated Schools, JEwish LifE, Feb. 1955, at 8.

34. See Klinkner \& SMith, supra note 2, at 343; see generally C. VAnn Woodward, The Strange Career of Jim Crow (1955). 
aggressively against this all-inclusive racial segregation, often to the point of losing their lives in the struggle. ${ }^{35}$

\section{Attending to the Black Perspective}

\section{Breakthrough Court Decisions: Black Pressures}

From the 1890 s to the 1930 s, the legal structure of racial segregation remained firmly in place, with few challenges that resulted in significant change. However, during the second and third decades of the 20th century, a slowly growing number of white jurists, public commentators, and politicians gradually began to move from outright rejection of black accounts of the oppressiveness of institutional racism to a closer attending to, if not acceptance of, these black accounts of discriminatory experiences. One major reason for this change was the growing pressure being brought by organized action on the part of African-Americans and their protest organizations such as the new NAACP (organized in the early 1900s). During the 1930s and 1940s, several federal court cases brought by the NAACP regarding university graduate programs resulted in Supreme Court decisions finally paying attention to the black view of racial matters. Thus in the 1938 case, Missouri ex rel. Gaines $v$. Canada, the white Justices for the first time in history ruled in favor of the black view of racial discrimination and segregation, the view expressed by NAACP lawyers: The state of Missouri program sending black (but not white) students to law schools outside that state did not provide the Plessy-required "separate but equal" education. ${ }^{36}$ In turn, this case became the basis for more aggressive presentations of the black perspective on racial segregation, and more sweeping successes, in University of Oklahoma (1948) and University of Texas (1950) cases involving graduate schools. ${ }^{37}$ These cases laid the foundation for the 1954-1955 Brown decisions knocking down public school segregation.

\section{Forgotten Reasons for Racial Change}

These school desegregation cases, and especially the 1954 Brown decision, have often been hailed as pioneering decisions by brave Supreme

35. Du Bois, supra note 33, at 8 .

36. Missouri ex rel. Gaines v. Canada, 305 U.S. 337 (1938). I am indebted to Roy Brooks for helpful comments on this section.

37. Sweatt v. Painter, 339 U.S. 629 (1950); Sipuel v. Bd. of Regents, 332 U.S. 631 (1948). 
Court Justices said to have been far in front of the country's leadership and citizenry: "[t]he Court was also aware that the judicial branch stood alone in the mid-1950s in its efforts to move the nation along a more progressive path in the area of race relations. ${ }^{.38}$ In fact, the Supreme Court decision in Brown was a weak decision and not way out in front of many progressive Americans. The Justices were not ahead, in reasoning or action, of AfricanAmericans - and many other Americans of color-or their leaders. AfricanAmericans not only were far in advance of the white public and leadership on these issues well before the 1930s, but African-Americans' organizing and voting were responsible for the northern white elite's increasing concern, by the 1930s and 1940s, to take action against the atrocities of lynching and, more generally, the totalitarian system of legal segregation. The civil rights movement actually changed the social face of the United States. Over the 1930s and 1940s, black civil rights groups were becoming much stronger and more numerous. By 1946, the NAACP had 1000 local organizations and onehalf million members. ${ }^{39}$ In addition, black veterans were returning in large numbers from World War II, a war ostensibly fought "for democracy," and many joined the growing civil rights movements against segregation. ${ }^{40}$

Most significantly, the number of black voters had grown substantially in the North since 1920 . This was a major reason for the increasingly pro-civilrights positions of presidents Franklin Roosevelt and Harry Truman. ${ }^{41}$ Both were also pressured by civil rights organizations to take action. The first significant efforts to end overt segregation came during the Roosevelt administration. In 1941, under pressure from A. Philip Randolph and other black leaders planning a March on Washington to protest discrimination, Roosevelt issued Executive Order 8802 reducing discrimination in wartime employment and setting up a Fair Employment Practices Committee. ${ }^{42}$ In the late 1940s, Truman desegregated the Armed Forces and established a President's Committee on Civil Rights, with an order asserting that civil rights were constitutionally guaranteed and necessary for free institutions. ${ }^{43}$ Some

38. Robert A. Pratt, Brown v. Board of Education Revisited, 30 Reviews In Am. Hist. 141, 144 (2002).

39. Nathan Newman, Remembering the Popular Will for Civil Rights: Robert Caro's Master of the Senate, Progressive Populist, June 15, 2002, available at http://nathannewman. org/populist/06.15.02pop.html (last visited Apr. 19, 2004).

40. $I d$.

41. See id.

42. See generally 1 KLUGER, supra note 18, at 273.

43. Truman Presidential Museum \& Library, Records of the President's Committee on Civil Rights, available at http://www.trumanlibrary.org/hstpaper/pccr.htm (search to "Agency History") (last 
white politicians in northern cities, like Chicago's Mayor Richard Daley, owed their positions in part to black voters and increasingly supported an end to legal segregation out of concern for these voters. ${ }^{44}$

Truman was the first president to work actively to end the discriminatory poll tax and discrimination in education and public accommodations, as well as to seek to enforce these laws with a new Department of Justice civil rights office. Yet, all his proposals (except for ending the poll tax) were blocked in Congress, mainly by segregationist southern senators. ${ }^{45}$ Interestingly, from the 1930 s to the 1950s majorities of U.S. House members, almost all white, periodically supported legislation to end lynching, to end the poll tax that blocked black voting, and to end much legal segregation. Yet, all such civil rights bills, except for a token 1957 civil rights bill, were killed in the Senate by arch-segregationist senators, mostly from southern states. ${ }^{46}$

\section{Increasing Pressures for Change}

Yet, the long-held power of the southern senators would soon decline for several reasons. By the mid-1950s, the civil rights movement had created a serious legitimation crisis for the ruling elite. The desire of this white elite for maintenance of its social and political legitimacy in face of protests and challenges from African-Americans was a central reason for the success of the civil rights movement. Without aggressive pressuring from black Americans and their leadership, the elite would not likely have moved toward desegregation. ${ }^{47}$ The great historian of U.S. racism, W.E.B. Du Bois, underscored this point:

Then in 1905 the Negroes organized [in what later was the NAACP] and began to fight back. Slowly they beat upon public opinion and then entered the courts. The courts dodged and evaded with every subterfuge, but they faced inevitably clear decisions unless the principle of democratic government was to be completely surrendered in the presence of world war in which we claimed to lead democracy. ${ }^{48}$

\footnotetext{
visited Apr. 18, 2004).

44. CARO, supra note 10 , at 775 .

45. Id. at $100-01$

46. See Newman, supra note 39 .

47. Joe R. Feagin, School Desegregation: A Political-Economic Perspective, in SCHOoL Desegregation: Past, Present, and Future 25, 29-35 (Walter G. Stephan \& Joe R. Feagin eds., 1980).

48. W.E.B. Du BoIs, What is the Meaning of "All Deliberate Speed," in W.E.B. Du Bors: A READER 419, 422 (David L. Lewis ed., 1995).
} 
Du Bois noted the important role not only of black organizations, but also of the war setting, in which the ideology of democracy was vigorously heralded against undemocratic enemies by the U.S. government. ${ }^{49}$ As Klinkner and Smith note, large-scale wars like World War II, the Korean War, and the Vietnam War have required substantial mobilization of black workers or soldiers for success. ${ }^{50}$ Such a situation makes it easier for the voices of African-Americans to be heard at the highest levels of power and decisionmaking, if only temporarily.

Elsewhere, Du Bois singled out another key factor making civil rights progress (and the Brown decision) much more likely. The decision "would not have been possible without the world pressure of communism led by the Soviet Union. It was simply impossible for the United States to continue to lead a 'Free World' with race segregation kept legal over a third of its territory." 51 The Cold War with the Soviet Union forced the United States to accent egalitarianism and democracy ever more in its international relations. The U.S. Department of Justice even submitted an amicus brief in the Brown case citing the need for the U.S. to look good on the international scene by removing such "existing flaws in our democracy" as racial discrimination; and attached to that brief was a statement from Secretary of State Dean Acheson making the same point, of "damage to our foreign relations" from discrimination, which gave "unfriendly governments the most effective kind of ammunition for their propaganda warfare." international scene was a growing concern for many in the elite. By the mid1950 s, and accelerating in the 1960s, the liberal wing of that elite was willing to more or less discard the Plessy doctrine of separate but equal, and soon the high Court handed down the pathbreaking Brown decisions.

\section{The Brown Decision: Paying Attention to Black Perspectives}

The graduate school cases in Missouri, Oklahoma, and Texas had laid the foundation for Brown, yet there were still large hurdles to be cleared. In the mid-1950s, the United States, and especially its southern region, was an extremely oppressive, overtly racist society. In the southern and border states racial segregation was all-encompassing and firmly entrenched, and few

\footnotetext{
49. See id. at $420-23$.

50. KLINKNER \& SMith, supra note 2, at 3-4.

51. W.E.B. Du Bois, The Autobiography of W.E.B. Du Bois 333 (1968).

52. KLINKNER \& SMith, supra note 2, at 235.
} 
people, black or white, dared to speak out against it. ${ }^{53}$ The southern region was a socially and politically repressive place for most of its people.

NAACP lawyers sought desegregation to secure equal educational opportunity. The NAACP-supported cases grouped as Brown pressed for an end to institutionalized discrimination in primary and secondary education, and they were brought under difficult conditions for black plaintiffs. In Brown, white Justices again took seriously the black perspective on institutional racism in schooling as articulated by the NAACP. At the heart of Brown is this broadly framed perspective written by Chief Justice Earl Warren:

We conclude that in the field of public education the doctrine of "separate but equal" has no place. Separate educational facilities are inherently unequal. Therefore, we hold that the plaintiffs and others similarly situated for whom the actions have been brought are, by reason of the segregation complained of, deprived of the equal protection of the laws guaranteed by the Fourteenth Amendment. ${ }^{54}$

In this decision, the Court rejected legal school segregation in the seventeen states that still specified or permitted it. With this broad framing, the Court held unanimously that in public education "separate but equal" no longer had any place. ${ }^{55}$ African-Americans were at last recognized as full citizens, a category to which they had long been denied. As Aleinikoff puts it, "[s]egregation in the public schools is condemned for producing secondclass citizenship for African-Americans both because it imposed a stigma on them (as persons not fit to go to school with whites) and because it did not adequately prepare them to be effective citizens. ${ }^{, 56}$

As Earl Warren wrote in Brown, he focused substantially on the harm that segregation does to the self-esteem and achievement of black children. Here, Warren and his colleagues relied to a degree on social science data about the experiences and perspectives of black children-for example, on Kenneth Clark's interviews with black children. ${ }^{57}$ A growing number of white jurists were coming to see that they had to pay some, if not substantial, attention to perspectives of African-Americans in regard to the character and impact of continuing racism.

53. See generally 1 Gunnar Myrdal, An American Dilemma: The Negro Problem and Modern Democracy 4 (1964).

54. Brown v. Bd. of Educ., 347 U.S. 483, 495 (1954).

55. $I d$.

56. T. Alexander Aleinikoff, Semblances of Sovereignty: The Constitution, the State, AND AMERICAN Citizenship 40 (2002).

57. Brown, 347 U.S. at 494 n.11. 
Also, as might be expected given the government briefs, the Brown Justices recognized the significance of the international setting in their comments that education is the "foundation of good citizenship" and necessary for "service in the armed forces." Soon after the decision, the Voice of America heralded it across the globe, and major newspapers and magazines noted it as a blow against Communism and for human equality and freedom. ${ }^{59}$

\section{The Moral Impact of BROWN}

While it clearly took an important step forward, the Warren Court was not on the cutting edge on issues of racial desegregation, for most AfricanAmericans and their leaders - and many whites in the U.S. House and the Executive Branch-were well ahead of the Court in both anti-discrimination understandings and legal action. As one lawyer and activist put it,

At best, the Supreme Court's timid steps against segregation can be characterized as one elitist institution bypassing the elitist power of another dominated by Southern Senators.... [I]t was not the Constitution that defeated segregation. In fact, for decades the Constitution's institutions had been defeating the popular will in favor of civil rights. ${ }^{60}$

However timid it was, the Brown decision nonetheless had an important social impact, as it was viewed by most people as a moral attack on segregation. As Mark Tushnet has noted, "[w]hen the Supreme Court said that segregation could not be reconciled with the Constitution, it told the nation that segregation was wrong. . . . Even today Brown stands as the Court's deepest statement on the central issue in American history-how Americans of all races should treat one another." ${ }^{\circ 1}$ Not surprisingly, Brown was taken by numerous judges as moral and legal authority to end much statecreated segregation, including that in public accommodations, voting, employment, and marriages.$^{62}$ Brown provided considerable support for rights activists, who "repeatedly invoked Brown in their political and moral arguments against segregation." ${ }^{\circ 3}$ For example, activists and leaders like

58. Id. at 493

59. KLINKNER \& SMith, supra note 2, at 239-40.

60. Newman, supra note 39 (italics added). (1995).

61. Mark V. Tushnet, BRoWN V. BOARD OF EDUCATION: THe BATtLe For INTEgRation 132, 136

62. 1 KLUGER, supra note 18 , at 946-947.

63. Tushnet, supra note 61, at 130. 
Dr. Martin Luther King, Jr., repeatedly referred to Brown and related Court decisions in their commentaries and speeches. ${ }^{64}$ Robert Carter, an NAACP lawyer in the Brown litigation, and later a federal judge, has explained why efforts to end school segregation were both important and necessary. Brown helped bring about "a radical social transformation in this country and whatever its limited impact on the educational community, its indirect consequences of altering the style, spirit, and stance of race relations will maintain its prominence in American Jurisprudence for many years to come." ${ }^{65}$ The dethroning of Plessy's doctrine of separate but equal as the legal standard was the task required before deeper problems of systemic racism could be attacked, for "[i]t was not until Brown I was decided that blacks were able to understand that the fundamental vice was not legally enforced racial segregation itself; that this was a mere by-product, a symptom of the greater and more pernicious disease — white supremacy." ${ }^{.66}$

\section{Extreme Reactions: Southerners Reject the Black Perspective}

The reaction of most whites in the South, both in the governing elite and in the general public, was hostility to Brown. Because of this massive white resistance, and collusion in it by then-President Dwight Eisenhower, very little desegregation came to southern schools from the 1954 to the mid-1960s. The racist stereotyping and hostility characteristic of the white majority in the South could be seen in the reactions of most of its members in Congress. Thus, in 1956 a "Declaration of Constitutional Principles" (the famous "Southern Manifesto") was signed by no fewer than 19 senators and 77 house members from the southern states. ${ }^{67}$ It began: "The unwarranted decision of the Supreme Court in the public school cases is now bearing the fruit always produced when men substitute naked power for established law." Brown decision, in their view, was a major abuse of Supreme Court power. The segregationist authors of this manifesto-primary among them the late Senator Strom Thurmond ${ }^{69}$ — point to the northern states as the pioneers of

64. Id. at 131 .

65. Robert L. Carter, A Reassessment of Brown v. Board, in Shades of BRown: New Perspectives on School Desegregation 21 (Derrick Bell ed., 1980).

66. Id. at 23 .

67. 102 Cong. ReC. 4459-4460 (1956) (Declaration of Constitutional Principles).

68. Id. at 4460 .

69. Note too, the hypocrisy of numerous white segregationists like Thurmond who argued vociferously for the "separation of the races." Thurmond had a child when he was in his early twenties by a sixteen-year-old black girl who worked for his family. See JACK BASs \& MARILYN W. ThOMPson, OL' 
school segregation, and assert further that the separate but equal doctrine sanctioned in Plessy had become part of the way of life for people in many states. $^{70}$

Writing without sensitivity to contradictions in their statement, influential members of the South's elite here argued that segregation is "founded on elemental humanity and commonsense, for parents should not be deprived by Government of the right to direct the lives and education of their own children." ${ }^{71}$ They meant the white parents and children of the South, for they did not even consider seriously the perspectives of black parents and children. The crescendo of protests stemming from the black population in the courts and streets should have signaled to them that extreme racial segregation was not founded on "elemental humanity," but rather on inhumanity and irrational prejudice. The view of this manifesto was from that of the stereotype-filled white mind, and there is no acknowledgment of the viewpoints of most African-Americans-who constituted a bit more than $20 \%$ of the southern population at the time (and who were even larger percentages of key southern states). ${ }^{72}$

Seething with anger against the Court for creating "chaos," the manifesto did not mention that most social disorder at that time was being created by rabid segregationists using violence and militancy in attempts to stop racial desegregation. These senators further asserted a hoary myth about the South: "[i]t is destroying the amicable relations between the white and Negro races that have been created through ninety years of patient effort by the good people of both races. It has planted hatred and suspicion where there has been heretofore friendship and understanding." "73 Again, we have only the white point of view in play, for it should have been obvious that a majority of black southerners, many of them involved in civil rights protests across the South, certainly did not share this rosy view of "amicable relations."

The hostility and single-mindedness of the white mindset can also be seen in commentaries of major journalists after the Brown decision. For example, in the 1950s and 1960s, the influential Richmond News-Leader editor (later, national columnist) James J. Kilpatrick, wrote in a key book that the South

\footnotetext{
Strom: An Unauthorized Biography of Strom Thurmond 275-86 (1998).

70. 102 Cong. Rec. 4460 (1956).

71. $I d$.

72. Campbell Gibson \& Kay Jung, Historical Census Statistics on Population Totals by Race, 1790 to 1990 for the United States, Regions, Divisions, and States (2002), available at http://www.census.gov/population/www/documentation/twps0056.html (last visited Apr. 20, 2004).

73. 102 Cong. ReC. 4460 (1956).
} 
had "a sense of oneness here, an identity, a sharing, and this quality makes the South unique"; indeed, the South is a "state of mind." 74 He titled this book The Southern Casefor School Segregation..$^{75}$ Yet again, in these and similarly expressed sentiments, the advocates were thinking only in terms of the views of the South's white majority. At the time, there was not-and there still is not- "the southern case." What Kilpatrick and other whites meant is the "white southern case." Black southerners mostly did not share such dreamy views of oneness, sharing, and a beneficent segregation.

In addition, some key white political and business leaders outside the South did not publicly support Brown, including, perhaps most importantly, Texas-born President Dwight D. Eisenhower. Robert Caro describes Eisenhower's collusion in the southern resistance-and the larger racist system - thus: "[n]ot once during those six years [after Brown] would Eisenhower publicly support the ruling; not once would he say that Brown was morally right, or that segregation was morally wrong." ${ }^{.76}$ Eisenhower did not even promise to support it with the full force of government. ${ }^{77}$ He only acted when forced to do so, as in the Little Rock high school situation where the Arkansas governor openly defied federal authority. Many powerful whites inside the South — and some outside as well — fought significant changes in segregation with all the might they could muster. Resistance was undeniably their motto, and they and less powerful whites constantly signaled that the extensive experiences of millions of black southerners with the brutality of institutionalized racism, and black views of the oppressiveness of racial apartheid, were unworthy of significant consideration.

\section{Resegregation of U.S. Schools: Discarding Black Perspectives}

\section{A Brief Era of Progress}

By the mid-1950s and early 1960s, many whites inside and outside the elite had decided that some reduction in racial segregation was necessary, and thus they paid more attention to the articulated perspectives of black Americans about societal desegregation. For a time after Brown I, the Supreme Court and other federal courts listened, albeit with much hesitation and waffling, to black perspectives on segregation and pressed forward, albeit

\footnotetext{
74. James J. Kilpatrick, The Southern Case for School Segregation 20-21 (1962).

75. See generallyid.

76. CARO, supra note 10 , at 778 .

77. KLINKNER \& SMith, supra note 2, at 246.
} 
hesitantly and slowly, with desegregation. Indeed, at first the Supreme Court was fearful about ordering the full and speedy implementation of its 1954 decision. While Brown I articulated some aspects of the black perspective on school desegregation, Brown II, the 1955 decision designed to implement Brown I, was clearly a response to the views of resisting whites. Rather than representing the views of most African-Americans, the Supreme Court took a position more acceptable to many whites: the Justices remanded the cases under consideration to federal district courts "to take such proceedings and enter such orders and decrees consistent with this opinion as are necessary and proper to admit to public schools on a racially nondiscriminatory basis with all deliberate speed the parties to these cases." ${ }^{78}$ Neither Brown I nor Brown II actually explained what racial segregation and desegregation were, and neither decision described and mandated the steps necessary to school desegregation. Neither had a sense of urgency. This lack of forcefulness is the key reason why there was little desegregation in the public schools from the 1950 s to the mid-1960s. It helps as well to explain the general failure of school desegregation from then to now.

Thus, it was not until the late 1960s and early 1970s that numerous federal courts actually began to force substantial desegregation in the South. For example, a critical 1968 Supreme Court case, Green v. County School Board of New Kent County ${ }^{79}$ held that freedom-of-choice desegregation plans were insufficient and pressured segregated school systems to eliminate segregation "root and branch." ${ }^{\prime 0}$ According to this decision, students, teachers, staff, transportation, and extracurricular facilities had to be desegregated. Moreover, the 1971 case of Swann v. Charlotte-Mecklenberg Board of Education, held that desegregation plans assigning students based on segregated residential patterns were insufficient and that busing should be used to desegregate if necessary. ${ }^{81}$ In this brief era of a court-articulated view of comprehensive school desegregation, the distinguished black jurist Thurgood Marshall provided needed moral leadership to the Court. For a time, his fellow Justices paid increasing attention to black views on thorough desegregation for school systems. The increased vigor of the Court's position was seen in its strong "root and branch" language, which indicated some recognition of institutionalized racism in school systems.

\footnotetext{
78. Brown v. Bd. of Educ., 349 U.S. 294 (1955) (italics added).

79. Green v. County Sch. Bd., 391 U.S. 430 (1968).

80. Id. at 438 .

81. Swann v. Charlotte-Mecklenberg Bd. of Educ., 402 U.S. 1 (1971).
} 


\section{Backtracking Again}

By the mid-1970s, however, renewed white resistance-often with a more disguised white-interest perspective-was working to end the slow movement to full desegregation of U.S. society. A more conservative Supreme Court has often led this backtracking. ${ }^{82}$ Legal scholar Jerome Culp has noted some ways in which the Supreme Court Justices have revealed a pervasive white-interest perspective in recent desegregation and affirmative action decisions:

First, the interests of black Americans are not considered important enough to be examined or put into the constitutional calculus - the interest blindness assumption. Second, the assumptions regarding factual circumstances, e.g., legislative intent, economic or social policy of social actors, posit that the status quo circumstances of black citizens are fair - the status quo blindness assumption. ${ }^{83}$

These are key dimensions of white-interest thinking today: Generally ignore black-majority perspectives and interests whenever possible and assume or assert, in the face of great evidence to the contrary, ${ }^{84}$ that U.S. society is actually mostly colorblind.

The end to two decades of desegregation efforts came in 1974 in a very influential Milliken v. Bradley decision, in which the majority of Justices (all white men)blocked a metropolitan-wide school desegregation plan combining the city of Detroit and its suburbs. ${ }^{85}$ In his dissent to Milliken, Marshall noted that after two decades of movement to desegregation, the Supreme Court was largely abandoning the goals and interests of African-Americans in eliminating the "badges" of slavery and segregation: "[o]ur precedents ... firmly establish that where, as here, state-imposed segregation has been demonstrated, it becomes the duty of the State to eliminate root and branch all vestiges of racial discrimination and to achieve the greatest possible degree of actual desegregation." ${ }^{86}$ In one incremental step after another, between the year of Milliken (1974) and the present, the Supreme Court and numerous other courts have retreated on earlier commitments to desegregate the schools "root and branch." Thus, in the key 1990s' cases of Board of Education of

82. Feagin, supra note 47 , at 40.

83. Jerome McCristal Culp, Jr., Understanding the Racial Discourse of Justice Rehnquist, 25 RutGers L.J. 597, 603 (1994).

84. See generally Joe R. Feagin, Racist America: Roots, Current Realities, and Future REPARATIONS 109-28 (2000).

85. Milliken v. Bradley, 418 U.S. 717 (1974).

86. Id. at 782 (Marshall, J., dissenting). 
Oklahoma v. Dowell $(1991)^{87}$ and Freeman v. Pitts (1992), ${ }^{88}$ the Court decided to permit gradual, if covert, resegregation of schools where there was no longer legally imposed racial segregation. In cases dealing centrally with segregation and discrimination since the 1980s, white perspectives and interests are again taking precedence over the black interests and perspectives, which are likely well-known to white decisionmakers.

\section{The Roller Coaster of Desegregation: The Renewed Separate but}

\section{EQual Policy}

After centuries of struggle, during the 1950s African-Americans were finally able to force public school desegregation, yet white elites have generally controlled how desegregation was implemented. First, these white elites worked for, or allowed, a decade of successful delay. Then, white officials grudgingly implemented desegregation plans that often eliminated many black teachers and principals - as well as many formerly black schools as critical community centers-while requiring more black than white children to engage in one-way busing to the newly desegregated schools. In these officially desegregated public schools, moreover, black (and Latino) children have often been mistreated and put into segregated tracks or classrooms. ${ }^{89}$ Few officially desegregated schools have ever been fully desegregated in terms of teachers, counselors, administrators, curriculum, and extracurricular activities - because many white parents and politicians did not want them to be so. Indeed, they often fired black teachers and replaced them with white teachers in order to please white parents sending their children to newly desegregated schools. For a time, across the country, many black children were mixed into historically white schools by means of busing, yet since the 1980s executive branch decisions and 1990s federal court decisions backing off on meaningful desegregation, black children have actually been resegregated - and, increasingly, on a large scale..$^{0}$ The conservative white (plus one black conservative) Supreme Court now articulates a resuscitated "separate but equal" view, yet predominantly black schools are rarely funded to be fully equal with white schools in all important facilities. "Separate but equal," again permissible under recent federal court decisions, is still the transparent fiction that it was for long decades after the Plessy decision.

87. Bd. of Educ. v. Dowell, 498 U.S. 237 (1991).

88. Freeman v. Pitts, 503 U.S. 467 (1992).

89. Joe R. Feagin \& Clairece B. Feagin, Racial and Ethnic Relations 185-87 (7th ed. 2003).

90. Id. at $186-87$. 
Today, large differences in per capita expenditures for children in predominantly white districts as compared with expenditures in districts predominantly comprised of children of color, are well documented, such as in a major 2001 report for the metropolitan area of Milwaukee. ${ }^{91}$

Today, the educational picture for many black and Latino children remains bleak. For that reason, many black and Latino parents have called for more efforts to improve the quality of their schools even if that means less desegregation. ${ }^{92}$ As key NAACP lawyer Robert Carter noted some time ago, predominantly black schools are often

woefully inadequate and provide no tools that will enable poor blacks to become a part of the mainstream of the social, economic, and political life of the country. In the short run, we have to concentrate on finding ways of improving the quality of education in these schools, even if it means or results in less effort being expended on school integration..$^{93}$

Indeed, writing about the first desegregated education in the mid-1930s, Du Bois wrote that a black parent

has a right to oppose any separation of schools by color, race, or class. . . . But . . . has no right, after he has made this academic pronouncement to send his own helpless immature child into school where white children kick, cuff or abuse him, or where teachers openly and persistently neglect or hurt or dwarf its soul . ... Let the N.A.A.C.P. and every upstanding Negro pound at the closed gates of opportunity and denounce caste and segregation; but let us not punish our own children under the curious impression that we are punishing our white oppressors. Let us not affront our own self-respect by accepting a proffered equality which is not equality, or submitting to discrimination simply because it does not involve actual and open segregation . . . ${ }^{94}$

Du Bois was arguing for both meaningful school desegregation and for the black community's control of black children's schooling experiences.

Some right-wing analysts of school desegregation, such as Stephan and Abigail Thernstrom, have missed this important point in their discussions of the substantial proportion of African-Americans (but less than the majority) who have questioned or resisted school desegregation. ${ }^{95}$ While whites have

91. See Rethinking Schools, The Return to Separate and Unequal: Metropolitan Milwauke School Funding Through a Racial Lens (2001), available at http://www.rethinkingschools.org/special_reports/prrac/pracexec.pdf (last visited Apr. 19, 2004).

92. FEAGIN \& FeAG IN, supra note 89, at 187.

93. Carter, supra note 65 , at 26.

94. W.E.B.Du Bois, Separation and Self-Respect, in W.E.B.Du Bois: A ReADER 559, 560 (David L. Lewis ed., 1995).

95. Stephan Thernstrom \& Abigail Thernstrom, America in Black and White: One 
opposed desegregation for racist reasons, the minority of African-Americans who have opposed it since the 1950s (and a majority supported it then as now) have questioned it because they feared that whites would implement desegregation in a way that would harm or destroy black institutions, such as black schools as traditional community centers, and that, as Du Bois suggests, white policy-makers would create desegregated situations where black children face hostile or unsupportive white parents, children, teachers, and administrators. In the past and present, African-Americans have supported community or school separation strategies mainly as a defense against whiteimposed, institutionalized racism that has continued in ostensibly desegregated institutions. As constitutional scholar Roy Brooks has put it, "there is an important distinction between segregation and separation that the Thernstroms miss. Segregation is involuntary racial isolation designed to subordinate and stigmatize. Separation is voluntary racial isolation designed to create a safe and supportive environment in the context of racial hostility."

Today, African-American parents face a severe dilemma in regard to education for their children. Desegregated school settings, while holding out promise of better resources, often remain hostile or unsupportive places for black children. This is not what black leaders and parents had in mind for their children as they pressed hard in the courts and legislatures for fullfledged school desegregation. Moreover, since the 1980s, instead of making the schools truly desegregated and supportive learning environments, most federal officials - including many federal judges like the majority on the Supreme Court - have retreated from the moral position of Brown to a renewed acceptance of the "separate but equal" fiction as local school board policy - that is, to accept to the discredited racist notions imbedded in the 1896 Plessy decision.

As a substantive review of segregation's history after Plessy reveals, such separate-but-equal policies do not generally work to improve school resources for children of color over the long term. ${ }^{97}$ The reason that this remains true today is clear: Generally speaking, those children and parents presently with the least in the way of school resources are also in communities with the least clout over the mostly white politicians who control federal and state money that is absolutely necessary to creating school equality at the local level. Without substantial political and economic clout, getting state and federal

NATION, INDIVISIBLE 103-04 (1997).

96. Roy Brooks, personal communication, December 2003; see also RoY BROOKS, INTEGRATION or Separation? A Strategy for Racial Equality 7-8 (1996).

97. See generally KLUGER, supra note 18, at 1-100. 
officials to provide the great and disproportionate governmental resources that would enable concentrated-poverty schools to become equal to middle-class schools is highly unlikely. ${ }^{98}$ Certainly, African-American children do not need white children in order to learn and thrive educationally, but in this still-racist society they will ordinarily get the full array of educational resources (human and material) that they need only if they are in school with children whose parents have this substantial economic and political clout - that is, children with middle-class and upper-middle-class white parents. ${ }^{99}$

\section{Conclusion: Is the United States a Democratic Society?}

The answer to this very important question remains negative at this juncture in U.S. history. The reality of systemic racism in U.S. society is that the white majority - including most white decisionmakers in local, state, and federal governments - have never listened seriously, or well, to the pained voices and racism-honed perspectives of African-Americans and other Americans of color. Most whites have never been strongly committed to a comprehensive desegregation of major U.S. institutions, including the public schools. At a few points in history a majority of whites have accepted some racial change, but their view of permissible change in racial segregation has been limited in time and force. Historically, periods of dismantling of aspects of the racist system have lasted only a decade or two, and then have been followed by many decades of white backtracking, retrenchment, and resegregation. This was true for the era after Reconstruction, as well as for the period since the civil rights movements and school desegregation decisions of the 1960s and 1970s.

Today, the central problem for the United States remains, as it has been since the 1700s, the racist mindset of the white majority — of ordinary whites and of those in the elite. Even as they participate in (or allow) racial discrimination, a majority of whites openly and contradictorily contend that anti-black discrimination and inequality no longer constitute serious national problems. ${ }^{100}$ As in previous centuries, most whites still remain opposed to any government policies that will bring substantial changes in continuing patterns of discrimination and inequality if those policies mean considerable surrender

98. Christopher Jencks \& Meredith Phillips, Introduction, in The Black-White Test Score GaP 9-45 (Christopher Jencks \&Meredith Phillips eds., 1998).

99. See Gary Orfield et al., Dismantling Desegregation: The Quiet Reversal of Brown V. BOARD OF EDUCATION at Xv, 73-113 (1996).

100. Joe R. Feagin \& Karyn D. McKinney, The Many Costs of Racism 10-12 (2003). 
of white power and privileges. While most whites will no longer openly assert blatantly racist ideas and perspectives, at least in public arenas, they do parrot apparently nonracist arguments that are but a thin veil over their continuing racist images and stereotyping, as well as their fears about true racial integration of the society. ${ }^{101}$ Nonetheless, changes that came in systemic racism after the Civil War and in the 1960s-1970s era do indicate that many whites can understand, and respond positively to, black-majority perspectives on discrimination and oppression. In my view, more such understandings, and anti-discrimination actions based on them, are essential if the U.S. is to survive the present century without great societal upheavals.

Today, ongoing demographic changes are pressuring many whites to rethink their racist proclivities and actions, as well as to rethink how they see the multicultural and multiracial future of the United States. White Americans today are less than half the populations of Hawaii, New Mexico, and of the two most populous states, California and Texas. ${ }^{102}$ They are a minority in half the country's 100 largest metropolitan areas. ${ }^{103}$ Over the next few decades they will become the minority in all the most populous states, as well as in all major metropolitan areas. ${ }^{104}$ By no later than the mid-2050s, demographers estimate, Americans of color will be more than half the U.S. population. ${ }^{105}$ While some whites are opting for apartheid-type reactions to these changes, such as joining anti-immigrant groups or white supremacist militias, moving into guarded-gated communities, moving away from the coasts into predominantly white areas in the Rocky Mountain or midwestern states, and putting their children into private schools, other whites seem welcoming of the changes toward a much more multiracial America. ${ }^{106}$

In the early 20th century, W.E.B. Du Bois articulated a strong argument for the importance of real racial integration and a respectful multiculturalism where a vibrant and sustainable democracy is truly desired: By leaving out some of the people - as is done in a racially segregated United States-we leave out "vast stores of wisdom. ${ }^{107}$ Only by bringing in the perspectives and experiences of all Americans can the United States expect to meet the hard

101. KLINKNER \& SMIth, supra note 2, at 327; see also Bobo et al., supra note 5, at 15-40; FEAG IN, supra note 77 , at $123-28$.

102. FEAGIN \& FEAGIN, supra note 89, at 341.

103. Id.

104. Id.

105. Id.

106. $I d$.

107. W.E.B. Du Bois, Darkwater, in The Oxford W.E.B. DuBois Reader, 481, 555 (Eric J. Sundquist ed., 1996). 
challenges of the unknown future. A great expansion of social and political democracy will make much essential knowledge finally available for the longterm development and improvement of democracies-in-the-making like the United States. ${ }^{108} \mathrm{Du}$ Bois underscores the importance of a very good education for all:

If we realized that children are the future, that immortality is the present child, that no education which educates can possibly be too costly, then we know that the menace of [wartime enemies is ] . . not a whit more pressing than the menace of ignorance, and that no nation tomorrow will call itself civilized which does not give every single human being college and vocational training free and under the best teaching force procurable for love or money. ${ }^{109}$

In the end, everyone benefits from a truly integrated society. As I have noted, black efforts during Reconstruction brought benefits not only for African-Americans but also for white southerners. The same was true for the civil rights movement of the 1950s-1960s. Without these black liberation struggles, white Americans themselves would very likely have fewer effective civil liberties today. These rights movements liberated the South, and in fact the whole country, from certain political and social straightjackets. Indeed, the South developed a fully modern economy and political system only after the Brown decision and the civil rights movement forced an official end to the legal segregation of southern society.

Unfortunately, over the last two decades, the Supreme Court has shown increasingly little understanding of the perspectives and experiences not only of African-Americans, but, more generally, of the 30 percent of Americans who are not white. Judicial stereotyping and misconceptions about racial matters, and narrow-mindedness focusing on white interests, is not in the longterm interest of the society, as Judge Carter has eloquently noted:

Justices on that Court must interpret the Constitution with the understanding that it is the fundamental law of a multiracial society. Without crosscultural sensitivity, it is virtually impossible to view the law with this perspective because one cannot see or feel beyond the limited scope of the narrow enclave or ethnic group within which one's own perceptions were formed..$^{110}$

108. Id. at 554-57.

109. Id. at 591 .

110. Robert L. Carter, Thirty-Five Years Later: New Perspectives on Brown, in RACE IN AMERICA: The Struggle for Equality 87-88 (Herbert Hill \& James E. Jones, Jr. eds., 1993). 
He adds that, "while a governmental official need not adopt the black or Hispanic perception" as his or her own, that official 'must respect it' if he or she is representing all the people."111

Even some leading white conservatives have realized the importance of paying significant attention to the experiential perspectives of those who are not white or European. In a commentary on affirmative action, celebrated legal theorist and judge, Richard Posner, has recognized this point:

Americans today are uncomfortable with racial classifications used to allocate public benefits and burdens, yet recognize that the disaffection of blacks poses a serious social problem. Although the problem may actually have been aggravated by affirmative action ... its sudden and complete elimination today throughout the public sector ... could not be 'sold' to blacks as the elimination of an unjust preference. It would instead be provocative, exacerbating racial tensions, which is something that, on pragmatic grounds, our society can ill afford. ${ }^{112}$

Posner has recognized a long-term, white-group interest in not generating great anger among African-Americans by getting rid of anti-discrimination programs such as affirmative action. The long-term health of a whitedominated society requires that the perspectives of African-Americans be taken into serious consideration. Still, as with most whites, Judge Posner failed to realize that he was writing from a distinctively white perspective. By "Americans" here, he of course meant white Americans, for most black Americans support remedial programs using racial classifications to undo past racial discrimination.

African-Americans and their allies in other racial-ethnic groups have pressed hard for change in the system of racism, and their movements have periodically pushed the United States in the direction of an expanded and more participatory democracy, generally to the benefit of all Americans. This movement needs a substantial renewal today. If the United States is to survive this century without sliding backward into a totalitarian system, the perceptive views in Judge Richard Posner's commentary, as well as the much deeper insights of Judge Robert Carter and sociologist W.E.B. Du Bois, must be implemented in the form of a thorough-going, racially integrated, comprehensive democracy for all Americans.

111. $I d$.

112. Richard A. Posner, The Problematics of Moral and Legal Theory 139 (1999). 